Arq. Bras. Med. Vet. Zootec., v.68, n.6, p.1721-1726, 2016

\title{
Climate conditions associated with the occurrence of pyrethroid residues in bulk milk tank
}

\author{
[Condições climáticas associadas à ocorrência de resíduos de piretroides em \\ amostras de leite de tanque] \\ L.C.A. Picinin ${ }^{1,2}$, I.M. Toaldo ${ }^{1}$, R.B. Hoff ${ }^{3}$, F.N. Souza ${ }^{4}$, M.O. Leite ${ }^{4}$, L.M. Fonseca ${ }^{4}$, S.A. Diniz ${ }^{4}$, \\ M.X. Silva ${ }^{4}$, J.P.A. Haddad ${ }^{4}$, M.M.O.P. Cerqueira ${ }^{4}$, M.T.B. Luiz ${ }^{1}$ \\ ${ }^{1}$ Universidade Federal de Santa Catarina - Florianópolis, SC \\ ${ }^{2}$ Centro de Ciências Agroveterinárias - Universidade do Estado de Santa Catarina - Lages, SC \\ ${ }^{3}$ Laboratório Nacional Agropecuário - Ministério da Agricultura Pecuária e Abastecimento - Porto Alegre, RS \\ ${ }^{4}$ Escola de Veterinária - Universidade Federal de Minas Gerais - Belo Horizonte, MG
}

\begin{abstract}
The present study attempted to identify climate conditions that are associated with the occurrence of pyrethroid residues using a multivariate principal component analysis (PCA). A total of 132 raw milk samples were collected from dairy farms in Minas Gerais State - Brazil and analyzed for seven analytes using gas chromatography with electron capture detection. Of the 132 milk samples, pyrethroid residues were identified in $14(10.6 \%)$ milk samples, of which $12(9.1 \%)$ and two $(1.5 \%)$ milk samples had the identification of cypermethrin and deltamethrin, respectively. From those samples, nine (6.8\%) milk samples were regarded as non-compliant for cypermethrin with this analyte concentration above the maximum residue limits set by Brazilian legislation. A PCA assessing pyrethroid residues in bulk tank milk demonstrated that the average temperature and the Temperature-Humidity Index were associated with pyrethroids residues in bulk milk tank, although the relative humidity was inversely correlated. Thus, the data analysis indicated that the pyrethrid residues associated with some climate conditions can predict the moments with higher risk of occurrence of pyrethroid residues in bulk tank milk.
\end{abstract}

Keywords: veterinary drug, pesticide, raw milk, seasonality, dairy cow

\section{RESUMO}

O presente trabalho objetivou identificar fatores climáticos associados à ocorrência de resíduos de piretroides em amostras de leite de tanque por análise multivariada de componentes principais (ACP). Para o presente trabalho, 132 amostras de leite cru foram coletadas em fazendas leiteiras localizadas no estado de Minas Gerais (Brasil) e analisadas por sete analitos por cromatografia gasosa com detector por captura de eletróns para detecção de resíduos de piretroides. Das 132 amostras de leite analisadas, a presença de resíduos de piretroides foi detectada em 14 amostras (10,6\%), e em 12 (9,1\%) e duas $(1,5 \%)$ foram detectados cipermetrina e deltametrina, respectivamente. Destas amostras, em nove (6,8\%) a concentração de cipermetrina encontrada foi maior que a permitida pela legislação brasileira. A ACP demonstrou que a presença de resíduos de piretroides no leite de tanque ocorreu menos frequentemente nos dias com maior umidade relativa, embora a presença desses resíduos estivesse associada a maior temperatura média e a maior índice de temperatura e umidade. Dessa forma, conclui-se que alguns índices climáticos podem predizer períodos com maior risco de ocorrência de resíduos de piretroides no leite de tanque.

Palavras-chaves: medicamento veterinário, pesticida, leite cru, sazonalidade, bovino leiteiro

Recebido em 16 de novembro de 2015

Aceito em 20 de abril de 2016

*Autor para correspondência (corresponding author)

E-mail: nogueirasouza@yahoo.com.br 


\section{INTRODUCTION}

Approximately one billion cattle, most of which are in the tropical and subtropical regions of the world, are at risk from various ectoparasites species causing significant production and economic losses. The control of ectoparasites found on animals (i.e. ticks and flies) is largely based on the use of chemicals, which include the synthetic pyrethroids. Therefore, the extensive and improper use of these active compounds can lead to the presence of their residues in milk causing human health risks (Fagnani et al., 2011; Raynal et al., 2013). Notably, pyrethroid compounds are toxic and can accumulate in an organism causing severe neurological (Heck et al., 2007; Roberts et al., 2012; Burns et al., 2013) and respiratory symptoms (Hudson et al., 2014), as well as adversely affecting endocrine and immune systems (Du et al., 2010; Costa et al., 2013).

As milk is an essential food, the maximum residue levels (MRLs) of veterinary drugs are markedly lower than in other food matrices, due in part to the recommended greater consumption of milk by young children and older individuals (Bilandžić et al., 2011; Roberts et al., 2012). Thus, in attempt to protect human health and ensure a high product quality, several governmental authorities (Brasil, 1999) have set maximum residue limits (MRLs) for various veterinary drug residues.

Thus, considering that climate conditions influence infestation by insects and ticks, such as horn flies (Haematobia irritans) and Rhipicephalus (Boophilus) microplus (Souza et al., 1988; Barros, 2001; Estrada-Peña et al., 2006; Paim et al., 2011), and the fact that the use of pyrethroids is mainly based on the subjective observation of infestation levels (Rocha et al., 2012), it was hypothesized that some climate condition parameters were associated with the occurrence of pyrethroid residues in bulk milk tank. For this reason, data on climate influences in pyrethroid residues in raw milk are of great relevance, particularly in tropical climate countries as Brazil, where different conditions of rainfall, relative humidity and temperature are perceived on unequable basis (Picinin et al., 2013). Thus, the present study aimed to identify the climate condition parameters that were associated with the occurrence of pyrethroids residues in bulk milk tank using a multivariate principal component analysis.

\section{MATERIALS AND METHODS}

Raw milk samples were collected from August 2009 to February 2010 from 45 dairy farms in Minas Gerais State, Brazil. A total of 132 samples were collected from bulk milk tanks after milk homogenization. Given the extensive sampling that was required and the costs of the analyses, dairy herds were randomly selected based on the list of farms from the most important dairy plant of the region by considering their levels of daily milk production. Twenty-seven $(60 \%)$ of the dairy farms had production levels of $\leq 500 \mathrm{~L} /$ day, five $(11.11 \%)$ had production levels between 501 and $1,000 \mathrm{~L} /$ day and $13(28.89 \%)$ had levels of $>$ $1,000 \mathrm{~L} /$ day. Thus, the milk samples that were obtained were representative of the dairy farms belonging to the region of study. Regarding the time period that was selected, this study was initiated in the dry period and finished in the rainy period, which resulted in great variability in climate conditions. This is representative of typical annual climate conditions that have been previously recorded based on official records of the Meteorological Center of the Minas Gerais State (Base..., 2011; Picinin et al., 2013). In the present study, a milk sample was assumed to be positive if any analytical residue was detected, regardless of the drug concentration. Furthermore, the sample was considered to be non-compliant if a drug was present at a concentration above the Brazilian MRL value (Brasil, 1999).

The milk samples were stored frozen at $-18^{\circ} \mathrm{C}$ until the quantitative analysis of pyrethroid residues was carried out.

The analytical standards $\gamma$-cyhalothrin $(\gamma \mathrm{CYH})$, $\lambda$-cyhalothrin $(\lambda \mathrm{CYH}), \quad$ cyfluthrin $(\mathrm{CYF})$, cypermethrin (CYP), deltamethrin (DEL), fenvalerate (FEV), and permethrin (PER), which all possessed levels of $95 \%$ certified purity, were obtained from Sigma-Aldrich (St. Louis, MO, USA). For the pyrethroids, standard stock solutions of $1 \mathrm{mg} \mathrm{mL}^{-1}$ were prepared individually in acetonitrile (ACN) and stored in a refrigerator at $8^{\circ} \mathrm{C}$. Working standard solutions containing all of the pyrethroids were diluted with ACN to give calibration solutions ranging 
from $5.0 \mathrm{ng} \mathrm{mL}^{-1}$ to $80.0 \mathrm{ng} \mathrm{mL}^{-1}$. All of the standard solutions were stored at $-20^{\circ} \mathrm{C}$.

The analytical system used for this study was a Trace GC Ultra gas chromatograph (Thermo Fisher Scientific, Milan, Italy) equipped with a splitless injection system, AI 3000 autosampler and ${ }^{63} \mathrm{Ni}$ electron-capture detector fitted with either an OV-5 fused silica capillary column $(15.0 \mathrm{~m} \times 0.25 \mathrm{~mm} \times 0.1 \mu \mathrm{m}$ film thickness $)$ or an OV-35 fused silica capillary column $(15.0 \mathrm{~m} \times$ $0.25 \mathrm{~mm} \times 0.25 \mu \mathrm{m}$ film thickness). The programmed temperature cycle for the $\mathrm{OV}-5$ column was as follows: $100^{\circ} \mathrm{C}(1 \mathrm{~min})$ to $250^{\circ} \mathrm{C}$ at a rate of $20^{\circ} \mathrm{C} \mathrm{min}^{-1}$, followed by an increase to $260^{\circ} \mathrm{C}(3 \mathrm{~min})$ at $5^{\circ} \mathrm{C} \mathrm{min}^{-1}$ and finally, to $330^{\circ} \mathrm{C}$ (5min) at $20^{\circ} \mathrm{C} \mathrm{min}^{-1}$. The conditions for pyrethroid separation using the OV-35 column were similar to those used for the OV-5 column. The injector and detector were programmed at $240^{\circ} \mathrm{C}$ and $340^{\circ} \mathrm{C}$, respectively. Nitrogen at $1.0 \mathrm{~mL} \min ^{-1}$ was used as the carrier gas. One microliter of each sample was injected in splitless mode. The identification of the peaks was based on comparisons of the retention times of compounds in the standard solutions.

The milk samples $(5.0 \mathrm{~mL})$ were extracted with $10 \mathrm{~mL}$ of $\mathrm{ACN}$ in $50 \mathrm{~mL}$ polypropylene tubes, shaken for $20 \mathrm{~min}$ and then incubated in a freezer at $-20^{\circ} \mathrm{C}$ for approximately 12 hours. After this period, the organic phase, which contained an organic solvent with the extracted compounds, remained as a liquid, whereas the aqueous phase and lipidic fraction of the milk froze. The supernatants were passed through previously cooled glass wool containing anhydrous sodium sulfate $(2.0 \mathrm{~g})$. The extracts were concentrated until dry in a water bath $\left(38-40^{\circ} \mathrm{C}\right)$ under gentle nitrogen flow. The residues were dissolved in $1.0 \mathrm{~mL}$ of $\mathrm{ACN}$ and analyzed by GC-ECD.

All of the methods have been fully validated and are currently in routine use in the laboratory network of the Ministério da Agricultura, Pecuária e Abastecimento (MAPA) for the National Residue Control Plan (Lins et al., 2012). The results were corrected for recovery. All of the applied methods met the internal criteria for residue analysis.

The relative humidity, the average temperature, and the maximum temperature were recorded at the day of milk sample collection. The rainfall was also recorded monthly. Furthermore, the Temperature-Humidity Index (THI) was calculated using the following equation: $\mathrm{THI}=$ $1.8 \times \mathrm{Ta}-(1-\mathrm{RH}) \times(\mathrm{Ta}-14.3)+32$, as described by Bouraoui et al. (2002) where Ta is the average temperature in ${ }^{\circ} \mathrm{C}$ and $\mathrm{RH}$ is the average relative humidity as a fraction of unit.

The statistical analyses were performed using the multidimensional principal component analysis (PCA) with the STATA statistical software version 12 (Stata Corp., College Station, Texas, USA). To test the associations among all of the variables that were surveyed together, a PCA was performed to assess inferences regarding the possible biological meanings underlying the associations among the variables without the preestablishment of cause/effect. Thus, this statistical technique allows us to graphically visualize the variables in the same dimensional plane and establish any relationships among them. The minimum percentage of inertia of the system for the multidimensional PCA was $65.0 \%$ in relation to the percentage of variance that was explained by the first three axes (components).

\section{RESULTS AND DISCUSSION}

The pyrethroid residues in raw milk were identified in $14(10.6 \%)$ milk samples, of which $12(9.1 \%)$ and two (1.5\%) milk samples had the detection of CYP and DEL, respectively. From those samples, nine (6.8\%) milk samples are regarded as non-compliant for CYP with concentrations above the maximum residue limits $\left(20 \mu \mathrm{g} \mathrm{kg}^{-1}\right)$ set by Brazilian legislation (Brasil, 1999). The presence of pyrethroid residues determined by GC-ECD in bulk milk tank samples here indicated that withdraw periods of pyrethroids drugs has not been fully respected by all dairy farmers. Another fact that can explain the pyrethroid residues in raw milk is the use of pesticides in products destined to animal feed that also leads to pyrethroid residues in raw milk (Fagnani et al., 2011). The presence of pyrethroid residues in raw milk should be emphasized considering their deleterious effect on human health (Heck et al., 2007; Du et al., 2010; Roberts et al., 2012; Burns et al., 2013, Costa et al., 2013; Hudson et al., 2014), and the fact that the raw milk is essential for the production of dairy products. In addition, it should be remembered that pyrethroid residues may be found in greater concentration in some 
milk products than milk from which these were manufactured (Li et al., 1970). Altogether, these data highlight the crucial importance of the dairy industry and government regulatory agencies in monitoring pyrethroid residues in milk combined with incentive, education, and training programs in an attempt to reduce the prevalence of excessive pyrethroid residue levels in raw milk.

The multidimensional PCA demonstrated that the average temperature and the THI were associated with pyrethroid residues in bulk milk tank, although the relative humidity was inversely correlated (Figure 1; Table 1). These facts strengthen our hypothesis that climate conditions influence the detection of pyrethroid residues in bulk milk tank probably as a result of the subjective use of pyrethroids mainly based on observation of infestation levels (Rocha et al., 2012) and the influence of climate conditions on infestation by ectoparasites (Estrada-Peña et al., 2006; Paim et al., 2011). With this in mind, Souza et al., (1988) described that lower infestation levels of Rhipicephaus (Boophilus) microplus, the major ectoparasite in cattle (Raynal et al., 2013), occurred during months (i.e. August and September) with low temperatures and high relative humidity, in contrast with higher infestation levels of Rhipicephaus (Boophilus) microplus during months with high temperature and low relative humidity (i.e. January and February) (Souza et al., 1988; Paim et al., 2011).

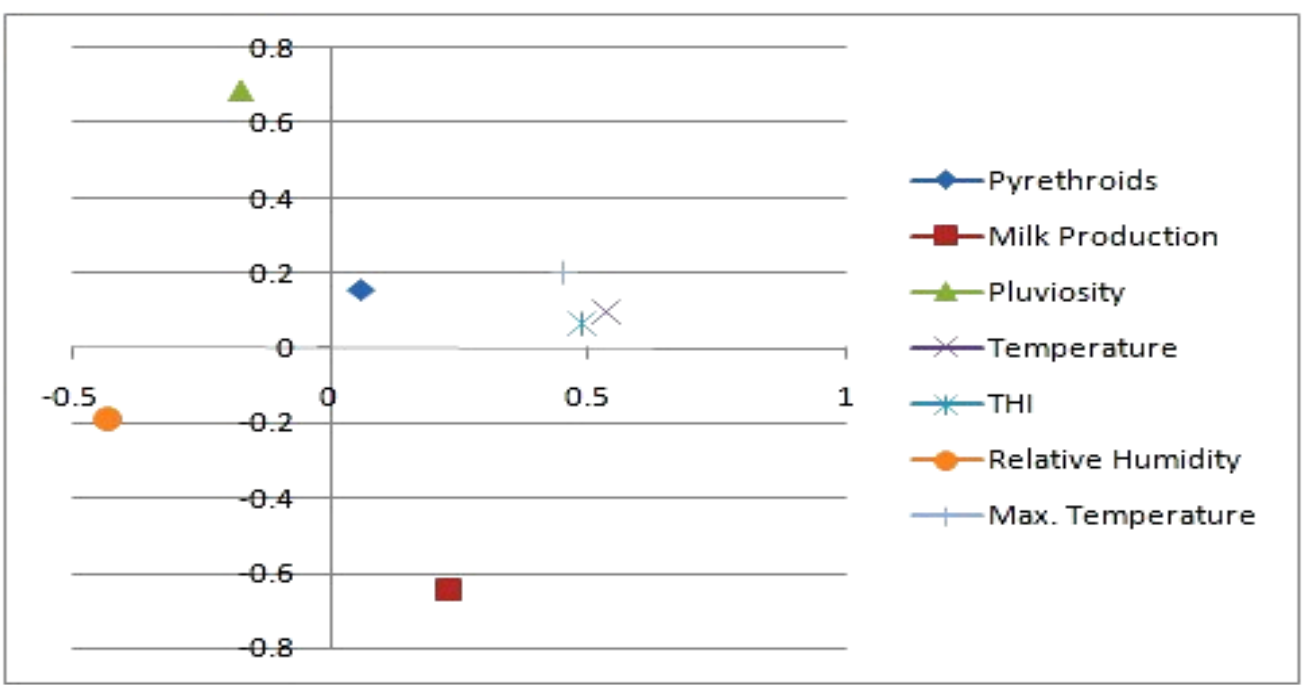

Figure 1. Plot of the principal multidimensional component analysis (PCA) of pyrethroid residues by confirmatory methods and their correlations with climate conditions - relative humidity, average temperature (temperature), maximum temperature (Max. temperature), pluviosity and the TemperatureHumidity Index (THI) for components 1 (x axis) and 2 (y axis) of the PCA. The variables in the same quadrant were closely associated, and those in opposite quadrants had opposite effects (components 1 and 2 ). The variables in other quadrants were regarded as independent variables.

Table 1. The relationship among milk production, climate conditions and pyrethroid residues by confirmatory tests expressed as loadings in a principal components analysis

\begin{tabular}{cccc}
\hline & \multicolumn{3}{c}{ Principal Component Analysis } \\
\hline Variables & Component 1 & Component 2 & Component 3 \\
\hline Pyrethroids & 0.0595 & 0.1561 & 0.9634 \\
Milk Production & 0.2288 & -0.6444 & -0.0626 \\
Pluviosity & -0.1724 & 0.6857 & -0.2371 \\
Temperature & 0.5341 & 0.0959 & -0.0272 \\
THI & 0.4878 & 0.0655 & -0.0348 \\
\hline Relative Humidity & -0.4309 & -0.1895 & 0.0201 \\
Maximum Temperature & 0.4533 & 0.2021 & -0.0964 \\
\hline
\end{tabular}


Although the present study evaluated the effect of climate conditions on the antimicrobial and macrocyclic lactone residues in raw milk in a short period, their importance should at least be regarded in terms of world climate change. The changes in temperature and rainfall patterns may lead to alterations on the dynamics of pathogens of veterinary importance (Gale et al., 2009; Van Dijk et al., 2010), and consequently on the veterinary drug usage and the presence of their residues in food of animal origin with important human health implications. Thus, further studies are required considering a longer term to better determine the effect of these changes on animal health, veterinary drug usage, and their residues in food of animal origin.

\section{CONCLUSIONS}

The results of the present study support the fact that some climate parameters can be associated with the residues in bulk tank milk. The data analyses indicated that some climate conditions can predict the moments with higher risk of occurrence of pyrethroid residues detected by confirmatory tests in bulk tank milk, and can be used to monitor pyrethroid residues in raw milk.

\section{ACKNOWLEDGMENT}

This study was supported by the Conselho Nacional de Desenvolvimento Científico e Tecnológico (CNPq), Ministério da Agricultura Pecuária e Abastecimento (MAPA), Pró-Reitoria de Pesquisa da Universidade Federal de Minas Gerais, and Laboratório de Análise da Qualidade do Leite (LabUFMG) of the Escola de Veterinária from the Universidade Federal de Minas Gerais. The authors are also very grateful to Gabriel Rübensam, Doriane Sacheto, Louise Jank, and Magda Targa Martin for their valuable assistance with the chemical analysis. This article is part of LCA Picinin Doctor (Ph.D.) degree in Food Science - Universidade Federal de Santa Catarina, Brazil.

\section{REFERENCES}

BARROS, A.T.M. Dynamics of Haematobia irritans (Diptera: Muscidae) infestation on nelore cattle in Pantanal, Brazil. Mem. Inst. Oswaldo Cruz, v.96, p.445-450, 2001.
BASE de dados meteorológicos e hidrológicos. Available in: <http://www.simge.mg.gov.br/>. Accessed in: 16 Apr. 2016.

BILANDŽIĆ, N.; KOLANOVIĆ, B.S.; VARENINA, I. et al. Veterinary drug residues determination in raw milk in Croatia. Food Control., v.22, p.1941-1948, 2011.

BOURAOUI, R.; LAHMAR, M.; MAJDOUB, A. et al. The relationship of temperaturehumidity index with production of dairy cows in Mediterranean cattle. Vet. Res., v.51, p.479-491, 2002.

BRASIL. Ministério da Agricultura, Pecuária e Abastecimento. Instrução Normativa $N^{\circ} .42$ de 20 de dezembro de 1999. Plano Nacional de Controle de Resíduos em Produtos de Origem Animal - PNCR. Diário Oficial da União, Brasília, 22 dez. 1999. Seção 1.

BURNS, C.J.; MCINTOSH, L.J.; MINK, P.J. et al. Pesticide exposure and neurodevelopmental outcomes: review of the epidemiologic and animal studies. J. Toxicol. Env. Health, v.16, p.127-283, 2013.

COSTA, C.; RAPISARDA, V.; CATANIA, S. et al. Cytokine patterns in greenhouse workers occupationally exposed to $\alpha$-cypermetrin: an observational study. Environ. Toxicol. Pharmacol., v.36, p.796-800, 2013.

DU, G.; SHEN, O.; SUN, H. et al. Assessing hormone receptor activities of pyrethroid insectides and their metabolities in receptor gene assays. Toxicol. Sci., v.116, p.58-66, 2010.

ESTRADA-PEÑA, A.; CORSON, M.; VENZA, J.M. et al. Changes in climate and habitat suitability for the cattle tick Boophilus microplus in its southern Neotropical distribution range. $J$. Vector Ecol., v.31, p.158-167, 2006.

FAGNANI, R.; BELOTI, V.; BATTAGLINI, A.P.P. et al. Organophosphorus and carbamates residues in milk and feedstuff supplied to dairy cattle. Pesqui. Vet. Bras., v.31, p.598-602, 2011.

GALE, P.; DREW, T.; PHIPPS, L.P. et al. The effect of climate change on the occurrence and prevalence of livestock diseases in Great Britain: a review. J. Appl. Microbiol., v.106, p.14091423, 2009. 
HECK, M.C.; DOS SANTOS, J.S.; BOGUSZ JUNIOR, S. et al. Estimation of children exposure to organochloride compounds through milk in Rio Grande do Sul, Brazil. Food Chem., v.102, p.288-294, 2007.

HUDSON, N.L.; KASNER, E.J.; BECKMAN, J. et al. Characteristics and magnitude of acute pesticide-reated illnesses and injuries associated with pyrethrin and pyrethroid exposures - 11 States, 2000 - 2008. Am. J. Ind. Med., v.57, p.1530, 2014.

LI, C.; BRADLEY, R.L.; SCHULTZ, L.H. Fate of organochlorine pesticides during processing of milk into dairy products. J. Assoc. Off. Agric. Chem., v.53, p.127-139, 1970.

LINS, E.S.; CONCEIÇÃO, E.S.; MAURICIO, A.Q. Evolution of a residue laboratory network and the management tools for monitoring its performance. Food Addit. Contam. A, v.29, p.490-496, 2012.

PAIM, F.; SOUZA, A.P.; BELLATO, V. et al. Selective control of Rhipicephalus (Boophilus) microplus in fipronil-treated cattle raised on nature pastures in Lages, state of Santa Catarina, Brazil. Rev. Bras. Parasitol. Vet., v.20, p.13-16, 2011.
PICININ, L.C.A.; CERQUEIRA, M.M.O.P.; VARGAS, E.A. et al. Influence of climate conditions on aflatoxin M1 contamination in raw milk from Minas Gerais state, Brazil. Food Control, v.31, p.419-424, 2013.

RAYNAL, J.T.; SILVA, A.A.B.; SOUSA, T.J. et al. Acaricides on Rhipicephalus (Boophilus) microplus from Bahia state North-Central region. Rev. Bras. Parasitol. Vet., v.22, p.71-77, 2013.

ROBERTS, J.R.; KARR, C.J. Pesticide exposure in children. Pediatrics, v.130, p.e1765-e1788, 2012.

ROCHA, C.M.B.M.; BRUHN, F.R.P.; LEITE, R.C. et al. Principal component analysis on the perceptions of milk producers about Rhipicephalus (Boophilus) microplus control in Minas Gerais. Rev. Bras. Parasitol. Vet., v.21, p.224-231, 2012.

SOUZA, A.P.; GONZALES, J.C.; RAMOS, C.I. et al. Seasonal variation of Boophilus microplus on the Santa Catarina plateau. Pesqui. Agropecu. Bras., v.26, p.627-630, 1988.

VAN DIJK, J.; SARGISON, N.D.; KENYON, F. et al. Climate change and infectious disease: helminthological challenges to farmed ruminants in temperate regions. Animal, v.4, p.377-392, 2010 . 